\title{
A comparison of titers of anti-Brucella antibodies of naturally infected and healthy vaccinated cattle by standard tube agglutination test, microtiter plate agglutination test, indirect hemagglutination assay, and indirect enzyme-linked immunosorbent assay
}

\author{
Anju Mohan ${ }^{1}$, Hari Mohan Saxena ${ }^{1}$ and Puneet Malhotra ${ }^{2}$
}

1. Department of Veterinary Microbiology, College of Veterinary Science, Guru Angad Dev Veterinary and Animal Sciences University, Ludhiana - 141 004, Punjab, India; 2. Department of Animal Genetics and Breeding, College of Veterinary Science, Guru Angad Dev Veterinary and Animal Sciences University, Ludhiana - 141004 Punjab, India.

Corresponding author: Hari Mohan Saxena, e-mail: hmsaxena@yahoo.com, AM: anz089@gmail.com, PM: dr.puneetmalhotra@rediffmail.com

Received: 07-04-2016, Accepted: 08-06-2016, Published online: 12-07-2016

doi: 10.14202/vetworld.2016.717-722 How to cite this article: Mohan A, Saxena HM, Malhotra P (2016) A comparison of titers of anti-Brucella antibodies of naturally infected and healthy vaccinated cattle by standard tube agglutination test, microtiter plate agglutination test, indirect hemagglutination assay, and indirect enzyme-linked immunosorbent assay, Veterinary World, 9(7): 717-722.

\begin{abstract}
Aim: We determined the antibody response in cattle naturally infected with brucellosis and normal healthy adult cattle vaccinated during calf hood with strain 19.

Materials and Methods: The antibody titers were measured by standard tube agglutination test (STAT), microtiter plate agglutination test (MAT), indirect hemagglutination assay (IHA), and indirect enzyme-linked immunosorbent assay (iELISA) as per standard protocols.

Results: The mean STAT titers were $1.963 \pm 0.345$ in infected cattle and $1.200 \pm 0.155$ in healthy vaccinated cattle. The difference was extremely significant $(p<0.0001)$. The mean MAT titers were $2.244 \pm 0.727$ in infected cattle and $1.200 \pm 0.155$ in healthy vaccinated cattle. The difference was very significant $(\mathrm{p}<0.005)$. The mean IHA titers in infected cattle were $2.284 \pm 0.574$, and those in healthy vaccinated cattle were $1.200 \pm 0.155$. The difference was extremely significant $(\mathrm{p}=0.0002)$. However, the difference in mean iELISA titers of infected cattle (1.3678 \pm 0.014$)$ and healthy vaccinated cattle $(1.367 \pm 0.014)$ was non-significant. The infected animals showed very high titers of agglutinating antibodies compared to the vaccinated animals. However, it cannot be ascertained whether these antibodies are due to vaccine or response to infection. Since the infected animals had been vaccinated earlier, the current infection may suggest that vaccination was unable to induce protective levels of antibody. The heightened antibody response after infection may also indicate a secondary immune response to the antigens common to the vaccine strain and wild Brucella organisms.
\end{abstract}

Conclusion: The brucellosis infected animals showed very high titers of agglutinating antibodies compared to the vaccinated animals.

Keywords: antibody titers, Brucella, brucellosis, Brucella abortus S19 vaccine, bovine brucellosis.

\section{I ntroduction}

Brucellosis is a major bacterial zoonosis of global importance. Brucellosis occurs worldwide but is much controlled in developed countries by routine screening of domestic animals and vaccination program. Clinical disease is still common in Middle East, Asia, Africa, South and Central America, the Mediterranean Basin, and the Caribbean. About 500,000 cases of human brucellosis are estimated to occur worldwide every year. It causes heavy economic loss to the animal industry through abortion, delayed conception, and temporary or permanent infertility in the affected animals [1].

Copyright: Mohan, et al. Open Access. This article is distributed under the terms of the Creative Commons Attribution 4.0 International License (http://creativecommons.org/licenses/by/4.0/), which permits unrestricted use, distribution, and reproduction in any medium, provided you give appropriate credit to the original author(s) and the source, provide a link to the Creative Commons license, and indicate if changes were made. The Creative Commons Public Domain Dedication waiver (http://creativecommons.org/ publicdomain/zero/1.0/) applies to the data made available in this article, unless otherwise stated.
Bovine brucellosis is endemic in all states of India. In India, the occurrence of brucellosis is to the extent of $10 \%$ in the marginal herds and $50 \%$ in organized farms, and the socio-economic impact of the disease was estimated to run over Rs. 500 crores annually. In Punjab, overall $17.7 \%$ prevalence of brucellosis was reported in cattle and buffaloes [2,3]. Brucellosis in animals is clinically characterized by late-term abortions and retention of placenta in females and orchitis and epididymitis in males, with excretion of organisms in semen, uterine discharges, and in milk [4]. Once infected, the animal may continue to shed bacteria and remains a source of infection to others for long period [3]. Mass vaccination is crucial for the control and eradication of bovine brucellosis. The widely used vaccine against brucellosis is derived from the smooth live vaccine strain (S19) for cattle. Although it has some undesirable traits, it has proven to be very useful under most conditions [5-7]. Brucella abortus S19 has been effective for the control of brucellosis 
in adult bovines and preventing abortion as well as decreasing the prevalence in herds [8].

The antibodies induced by vaccination interfere in serological diagnosis of brucellosis. Little data are available in the published literature on comparison of antibody titers due to vaccination and those due to natural infection in cattle. The present study was, therefore, undertaken to explore this aspect of serology of bovine brucellosis.

\section{Materials and Methods \\ Ethical approval}

All the experimental protocols performed on cattle were approved by the Institutional Animal Ethics Committee (IAEC). Animals were kept in IAEC approved facilities and received feed and water ad libitum.

\section{I nfected and vaccinated cattle}

A total of 15 naturally infected brucellosis positive adult cattle, which were vaccinated during calf hood with B. abortus strain 19 vaccine (Bruvax; Indian Immunologicals), and 6 normal healthy calf hood vaccinated Holstein-Friesian crossbred adult cattle maintained at the University Dairy Farm were included in the study.

\section{B. abortus strain 19 (vaccine strain)}

The standard vaccine strain B. abortus strain 19, procured from the Biological Standardization Division, IVRI, Izatnagar, was used in the present study.

\section{Collection of serum}

Blood samples were collected from cattle through jugular vein for obtaining sera for studying the humoral immune response of the animals. Sera were separated and stored at $-20^{\circ} \mathrm{C}$ until further use.

\section{Analysis of immune responses}

Rose Bengal plate agglutination test (RBPT)

Equal volumes (10 $\mu 1$ each) of RBPT colored antigen (Punjab Veterinary Vaccine Institute, Ludhiana) and test serum were mixed on a clean glass slide [9] with the help of a sterilized toothpick. The slide was observed for $4 \mathrm{~min}$ for the formation of clumps. The formation of clumps was considered a positive test, whereas the absence of clear clumps was considered a negative reaction.

\section{Estimation of antibody titers by standard tube agglu-} tination test (STAT)

The standard OIE method [10] was followed (Table-1). The highest serum dilution showing 50\% agglutination was taken as the end point for the titer. A titer of 1:40 or above was considered positive.

\section{Controls}

1: Tube No. 08 - $25 \%$ agglutination

2: Tube No. $09-50 \%$ agglutination

3: Tube No. $10-75 \%$ agglutination.

\section{Microtiter plate agglutination test (MAT)}

MAT was performed as per the method reported earlier [11].

\section{Procedure}

a. Serum samples were serially diluted two-fold in a final volume of $100 \mu 1$ in 96 well U-bottom microtiter plate (Tarsons)

b. Equal volume of $100 \mu \mathrm{l}$ B. abortus plain antigen (Punjab Veterinary Vaccine Institute, Ludhiana) was added to each well. Negative control well containing $100 \mu \mathrm{l}$ of sterilized normal saline solution (NSS) and $100 \mu \mathrm{l}$ of the antigen was also kept

c. The plate was covered with a lid and incubated at $37^{\circ} \mathrm{C}$ for $24 \mathrm{~h}$ followed by incubation at $4^{\circ} \mathrm{C}$ for $1 \mathrm{~h}$

d. The formation of matt signified agglutination while button formation was indicative of a negative reaction. Titers ( $\log _{10}$ values) were recorded as the reciprocal of the highest dilution of the serum giving at least $50 \%$ agglutination.

\section{Indirect hemagglutination assay (I HA)}

The method reported earlier [12] was followed with minor modifications.

\section{Fixation of sheep red blood cells (sRBCs)}

Sheep blood was collected aseptically by jugular vein puncture into Alsever's solution (1:1) and kept at $4^{\circ} \mathrm{C}$ for 7 days before further processing. The

Table-1: STAT protocol.

\begin{tabular}{|c|c|c|c|c|}
\hline Tube No. & $\begin{array}{l}\text { Carbol saline } \\
\quad \text { (in ml) }\end{array}$ & Test serum (in $\mathrm{ml}$ ) & $\begin{array}{l}\text { B. abortus plain } \\
\text { antigen (in ml) }\end{array}$ & $\begin{array}{c}\text { Final } \\
\text { dilution }\end{array}$ \\
\hline 1 & 0.8 & 0.2 & 0.5 & $1: 10$ \\
\hline 2 & 0.5 & $\begin{array}{l}\text { Serial dilution was performed after thorough mixing. } \\
0.5 \mathrm{ml} \text { of the contents was transferred from tube No. } 1 \\
\text { to the next tube up to tube No. } 7 \text {. Finally, } 0.5 \mathrm{ml} \text { of the } \\
\text { contents was discarded from tube No. } 7\end{array}$ & 0.5 & $1: 20$ \\
\hline 3 & 0.5 & & 0.5 & $1: 40$ \\
\hline 4 & 0.5 & & 0.5 & $1: 80$ \\
\hline 5 & 0.5 & & 0.5 & $1: 160$ \\
\hline 6 & 0.5 & & 0.5 & $1: 320$ \\
\hline 7 & 0.5 & & 0.5 & $1: 640$ \\
\hline 8 & 1.25 & & 0.75 & \\
\hline 9 & 1.50 & & 0.50 & \\
\hline 10 & 1.75 & & 0.25 & \\
\hline
\end{tabular}

STAT $=$ Standard tube agglutination test, $\mathrm{B}$. abortus=Brucella abortus 
blood was then centrifuged at $1500 \mathrm{rpm}$ for $10 \mathrm{~min}$ to pack the erythrocytes. The packed RBCs were washed three times with 5-6 volumes of chilled NSS by centrifugation. Finally, a $10 \%(\mathrm{v} / \mathrm{v})$ suspension of RBCs was prepared in chilled NSS and stored at $4^{\circ} \mathrm{C}$.

\section{Fixation and treatment of sRBCs with tannic acid}

a. A $1 \% \mathrm{v} / \mathrm{v}$ solution of glutaraldehyde was prepared in NSS and stored at $4^{\circ} \mathrm{C}$. Equal volumes of chilled glutaraldehyde solution and 10\% washed sRBC suspension were mixed and allowed to stand at $4^{\circ} \mathrm{C}$ for $30 \mathrm{~min}$ with intermittent gentle stirring.

b. The sensitized sRBCs were packed by centrifugation at $1500 \mathrm{rpm}$ for $10 \mathrm{~min}$ at room temperature followed by three washes in NSS to remove free glutaraldehyde and resuspended in the same buffer containing $0.1 \%$ sodium azide to yield a $10 \%$ suspension of sRBCs. The glutaraldehyde fixed sRBCs (G-sRBCs) were then stored at $4^{\circ} \mathrm{C}$.

c. A $10 \%$ suspension of G-sRBCs was mixed with an equal volume of phosphate-buffered saline (PBS) containing $0.005 \%$ tannic acid (w/v) and incubated at $37^{\circ} \mathrm{C}$ with occasional shaking. The tanned G-sRBCs (TG-sRBCs) were pelleted by centrifugation at $650 \times \mathrm{g}$ for $10 \mathrm{~min}$ at room temperature and washed three times with PBS to yield a $10 \%$ suspension.

\section{Preparation of antigen}

The antigen prepared as described earlier was heated at $56^{\circ} \mathrm{C}$ for $30 \mathrm{~min}$ in a water bath with frequent shaking. Heat treated suspension was then centrifuged at $8000 \mathrm{rpm}$ for $15 \mathrm{~min}$ at $4^{\circ} \mathrm{C}$. The clear supernatant was separated and stored at $-20^{\circ} \mathrm{C}$ until use.

\section{Sensitization of TG-sRBCs with antigen}

a. One volume of packed RBCs and 15 volumes of the antigen were mixed and incubated for 1-2 $\mathrm{h}$ at $37^{\circ} \mathrm{C}$ in a water bath with frequent shaking

b. The sensitized cells thus prepared were washed 3 times with NSS by centrifugation at $2000 \mathrm{rpm}$ for $5 \mathrm{~min}$. After the final wash, packed cells were resuspended in chilled NSS to obtain 1\% suspension.

\section{Adsorption of serum samples}

a. To remove the heterophile antibodies, all the test serum samples ( 3 volumes) were adsorbed with packed sRBCs (1 volume) for $2 \mathrm{~h}$ at $37^{\circ} \mathrm{C}$ with periodic shaking before the test proper. The RBCs were removed by centrifugation

b. The suspension was centrifuged at $600 \times g$ for $15 \mathrm{~min}$ at $4^{\circ} \mathrm{C}$ in a refrigerated centrifuge. The supernatant was collected and used for the test.

\section{Test protocol for IHA}

a. PBS $(160 \mu \mathrm{l})$ and inactivated adsorbed serum $(40 \mu \mathrm{l})$ were added to the first well ( 1 in 4 dilution), and $100 \mu \mathrm{l}$ of PBS was added to all the other wells of a 96 well U-bottom microtiter plate (Tarsons). Two-fold serial dilutions of serum were made in a final volume of $100 \mu \mathrm{l}$ b. An equal volume $(100 \mu l)$ of the $0.5 \%$ sensitized $\mathrm{RBC}$ suspension was added to all the wells. The plates were shaken and left at room temperature for $2 \mathrm{~h}$.

Coarse agglutination of RBCs (matt formation) indicated a positive result and formation of a small button of deposited cells was considered as a negative result.

\section{Controls}

The following three controls were included with each test:

- Antigen control: $100 \mu 1$ of sensitized and adsorbed RBCs

- RBC control: $100 \mu 1$ of $1: 4$ dilution of serum and $100 \mu 1$ of sensitized RBCs

- Serum control: $100 \mu 1$ of untreated erythrocytes and $100 \mu 1$ of test sera.

\section{Enzyme-linked immunosorbent assay (ELISA)}

The serum samples of cattle were tested using Brucellosis Serum ELISA test kit (Idexx). The kit is based on indirect ELISA (iELISA) using inactivated antigen of $B$. abortus. The binding of the antibodies in cattle serum samples with precoated inactivated antigen on microtiter plate is detected by peroxidase-labeled anti-ruminant immunoglobulin $\mathrm{G}$ $(\mathrm{IgG})$. The degree of the color that develops (optical density [OD] measured at $450 \mathrm{~nm}$ ) is directly proportional to the amount of antibody specific for $B$. abortus present in the sample. The diagnostic relevance of the result is obtained by comparing the OD in wells containing the samples with the OD from wells containing the positive control. Antibody titers were calculated using an equation of regression.

\section{Procedure}

All reagents were thawed to $25^{\circ} \mathrm{C}$ and mixed by gentle vortexing before use.

a. Dispensed $90 \mu 1$ of diluted wash solution (1:10) into each well of the microtiter plate

b. Added $10 \mu \mathrm{l}$ of the undiluted serum samples and controls into the appropriate wells of the microtiter plate making the final dilution 1:10

c. Mixed the contents within each well by gently shaking the microtiter plate

d. Covered the microtiter plate with a lid and incubated for $60 \mathrm{~min}$ at $37^{\circ} \mathrm{C}$ in a humid chamber

e. Washed each well with approximately $300 \mu 1$ wash solution 3 times. Aspirated liquid contents of all the wells after each wash. Following the final aspiration, firmly tapped the residual wash fluid from each plate onto absorbent material. Drying of plate between washes and before the addition of the next reagent was avoided

f. Dispensed $100 \mu 1$ conjugate into each well

g. Covered and incubated the microtiter plate for 60 min at $37^{\circ} \mathrm{C}$ in a humid chamber

h. Washed each well and aspirated the liquid contents of all the wells after each wash 
i. Dispensed $100 \mu$ lof 3,3',5,5'-Tetramethylbenzidine substrate into each well and incubated the substrate at $18-26^{\circ} \mathrm{C}$ for $15 \mathrm{~min}$

j. Stopped the color reaction by adding $100 \mu$ of stop solution per well

k. The OD was recorded in an ELISA reader at a wavelength of $450 \mathrm{~nm}$.

\section{Calculation of antibody titers}

Antibody titer $\left(\log _{10}\right) Y=a+b x$

Where, constant $\mathrm{a}=1.35$; constant $\mathrm{b}=0.05 ; \mathrm{X}=\mathrm{OD}$ value of a test well/Mean +3 standard deviation value of negative control wells. The standard error of the Y estimate (antibody titer) was $+0.19 \log _{10}$.

\section{Statistical analysis of data}

Data pertaining to antibody titers by STAT, MAT, IHA, and iELISA were statistically analyzed by analysis of variance and t-test.

\section{Results and Discussion}

Antibody titers of infected or vaccinated cattle were estimated by STAT, MAT, IHA, and iELISA (Tables-2 and 3, Figure-1). STAT revealed the mean titers in infected cattle to be $1.963 \pm 0.345$, and the corresponding values in healthy vaccinated cattle were $1.200 \pm 0.155$. The difference was extremely significant $(\mathrm{p}<0.0001)$. The mean MAT titers in infected cattle were $2.244 \pm 0.727$, and the corresponding values in healthy vaccinated cattle were $1.200 \pm 0.155$. The difference was very significant $(\mathrm{p}<0.005)$. IHA revealed the mean titers in infected cattle to be $2.284 \pm 0.574$, and the corresponding values in healthy vaccinated cattle were $1.200 \pm 0.155$. The difference was extremely significant $(\mathrm{p}=0.0002)$. Interestingly, the difference between the mean iELISA titers of infected cattle $(1.3678 \pm 0.014)$ and healthy vaccinated cattle $(1.367 \pm 0.014)$ was non-significant.

Even though a number of antigenic components of Brucella have been characterized, the antigen that dominates the antibody response is the lipopolysaccharide (LPS). Numerous outer and inner membrane, cytoplasmic, and periplasmic protein antigens have also been characterized. Some are recognized by the immune system during infection and are potentially useful in diagnostic tests. The L7/L12 ribosomal proteins are important in stimulating cell-mediated responses [13].

Immune response of host to Brucella infection is mediated through both humoral and cell-mediated immunity [14]. The role of humoral immunity against intracellular bacterial infections is limited and not protective. Antibody-mediated opsonization by Igs (IgM, IgG1, IgG2a, and IgG3) enhances phagocytic uptake of bacteria, limiting the level of initial infection with Brucella but has little effect on the intracellular course of Brucella infection [15,16].

B. abortus strain 19 is used as a live vaccine and is normally given to female calves aged between 3 and 6 months as a single subcutaneous dose of 5-8 $\times 10^{10}$ viable organisms. It is believed to induce protective

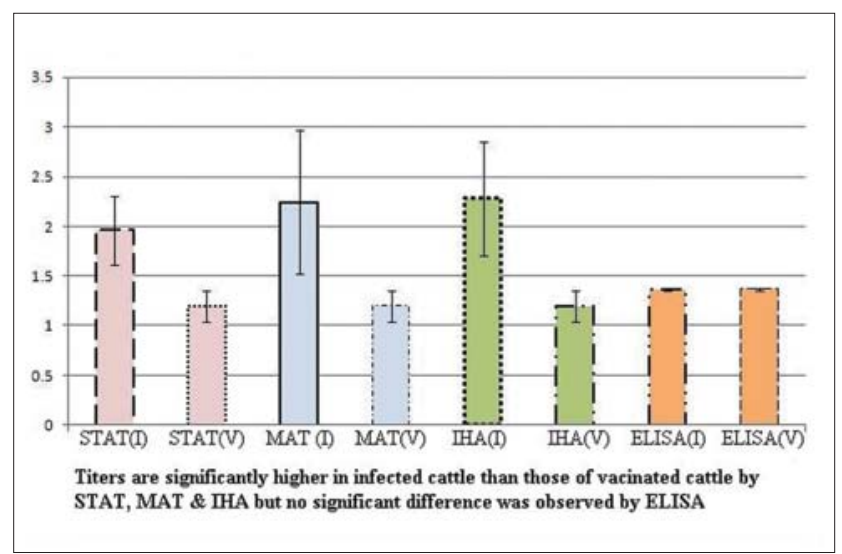

Figure-1: Antibody titers in brucellosis infected or vaccinated cattle by standard tube agglutination test, microtiter plate agglutination test, indirect hemagglutination assay test, and indirect enzyme-linked immunosorbent assay.

Table-2: Antibody titers of cattle naturally infected with brucellosis.

\begin{tabular}{lcccc}
\hline S. No. & \multicolumn{4}{c}{ Antibody titers $\left(\log _{\mathbf{1 0}}\right)$} \\
\cline { 2 - 5 } & STAT & MAT & I HA & iELI SA \\
\hline 1 & 1.903 & 2.204 & 2.204 & 1.4259 \\
2 & 2.204 & 3.107 & 3.408 & 1.4328 \\
3 & 1.602 & 3.408 & 2.505 & 1.4296 \\
4 & 1.903 & 3.107 & 3.107 & 1.4264 \\
5 & 1.602 & 1.602 & 1.602 & 1.3615 \\
6 & 2.204 & 1.602 & 1.903 & 1.4226 \\
7 & 2.806 & 3.709 & 3.107 & 1.4243 \\
8 & 1.903 & 2.204 & 2.505 & 1.4251 \\
9 & 1.602 & 1.903 & 1.602 & 1.3878 \\
10 & 2.204 & 1.602 & 2.505 & 1.4539 \\
11 & 1.602 & 1.903 & 1.903 & 0.6101 \\
12 & 1.602 & 1.602 & 1.602 & 1.2935 \\
13 & 2.204 & 1.602 & 1.903 & 0.4963 \\
14 & 1.903 & 1.903 & 2.204 & 1.4084 \\
15 & 2.204 & 2.204 & 2.204 & 1.4732 \\
MeantSD & $1.963 \pm 0.345$ & $2.244 \pm 0.727$ & $2.284 \pm 0.574$ & $1.3678 \pm 0.014$ \\
\hline
\end{tabular}

$\mathrm{SD}=$ Standard deviation, STAT $=$ Standard tube agglutination test, MAT=Microtiter plate agglutination test, IHA=Indirect hemagglutination assay test, iELISA=I ndirect enzyme-linked immunosorbent assay 
Table-3: Antibody titers of healthy cattle vaccinated with B. abortus strain 19 vaccine.

\begin{tabular}{lcccc}
\hline S. No. & \multicolumn{4}{c}{ Antibody titers $\left(\log _{\mathbf{1 0}}\right)$} \\
\cline { 2 - 5 } & STAT & MAT & I HA & iELISA \\
\hline 1 & 1.301 & 1.301 & 1.301 & 1.361 \\
2 & 1.301 & 1.301 & 1.301 & 1.361 \\
3 & 1.301 & 1.301 & 1.301 & 1.361 \\
4 & 1.000 & 1.000 & 1.000 & 1.361 \\
5 & 1.000 & 1.000 & 1.000 & 1.367 \\
6 & 1.301 & 1.301 & 1.301 & 1.396 \\
Mean+SD & $1.200 \pm 0.155$ & $1.200 \pm 0.155$ & $1.200 \pm 0.155$ & $1.367 \pm 0.014$ \\
\hline
\end{tabular}

$\mathrm{SD}=$ Standard deviation, STAT $=$ Standard tube agglutination test, MAT=Microtiter plate agglutination test, IHA=I ndirect hemagglutination assay test, iELISA=Indirect enzyme-linked immunosorbent assay

immunity against B. abortus in cattle [17]. However, the effectiveness of this vaccine varies with the age of vaccination, dose, route, and prevalence of brucellosis in the herd [18]. B. abortus strain 19 vaccine remains a reference vaccine to which any other vaccine is compared. Persistent antibodies could be detected up to $10-11$ months post-vaccination [19].

As evident from our present data, infected animals have very high titers of antibodies compared to the vaccinated animals. However, the high titers do not indicate whether these are protective antibodies due to vaccine or acute response to infection in the absence of a differentiation of infected from vaccinated animals (DIVA) assay or whether they are of any relevance to prognosis. Since the infected animals were the ones who had already been vaccinated during calf hood, the infection in these animals may suggest that the vaccine was unable to induce protective levels of antibody. Second, the heightened antibody response after infection may indicate a secondary immune response to the genus-specific antigens of Brucella.

The different titers observed in the same animals by agglutination assays (STAT, MAT, and IHA) and IELISA can be reconciled with the fact that these assays target antigens of different nature, i.e., agglutination assays are directed toward particulate antigens, whereas ELISA detects immune response to soluble antigens. ELISA is generally used to detect IgG antibodies [20]. In brucellosis, specific IgM antibodies dominate during the acute phase of the disease [21]. Specific $\operatorname{IgG}$ antibodies are present in the serum of patients at later stages of the illness and in the serum of relapsing patients [22]. ELISA is used to discriminate between the presence of specific IgM and IgG antibodies and to roughly assess the stage of illness [23].

In many countries, STAT is the routine diagnostic test for human and animal brucellosis. It has been reported [24] that STAT has a greater accuracy than that of the RBPT (93.3\% and $76.6 \%$, respectively). In a study [25], Brucella antibodies were investigated in bovine sera by RBPT, serum agglutination test, MAT, and 2-mercaptoethanol MAT, and MAT was determined as a fast, reliable, and economic test. On evaluation of canine brucellosis by MAT, it was shown [26] that MAT was more sensitive, simpler to perform, and easier than tube agglutination test.
A study [27] has shown that the use of sheep erythrocytes sensitized with a specific LPS antigen in the IHA test provided a specific method, which is more sensitive than the agglutination test. A study [28] was carried out to compare the efficacy of RBPT, STAT, and DotELISA in immunological detection of antibodies to B. abortus in sera. The study revealed that DotELISA was the most sensitive of the three tests used. In a study by Ghodasara et al. [29], STAT and iELISA were compared for detection of Brucella antibodies in cows and buffaloes. The seropositivity was found highest by iELISA (25\%) followed by STAT (14.45\%). iELISA, RBPT, MAT, and PCR were evaluated [30] for diagnosis of brucellosis in buffaloes, and it was concluded that iELISA detected more samples as positive among these tests. Currently, no DIVA vaccine against brucellosis is available in the market. Identification of extracellular proteins from Brucella may aid in discovery of better vaccines or diagnostic molecules [31].

Since cell-mediated immunity is known to play an important role in brucellosis, it would be pertinent to incorporate antigens and adjuvants in the vaccine which could generate cellular immunity of a high protective level to be effective in control of brucellosis.

\section{Conclusion}

We determined the antibody titers by STAT, MAT, IHA, and ELISA in cattle naturally infected with brucellosis and normal healthy adult cattle vaccinated during calf hood with strain 19 . The differences between the mean STAT, MAT, and IHA titers of infected cattle and healthy vaccinated cattle were highly significant $(\mathrm{p}<0.0001, \mathrm{p}<0.005$, and $\mathrm{p}=0.0002$, respectively). However, the difference in mean iELISA titers of infected cattle and healthy vaccinated cattle was non-significant. The infected animals showed very high titers of agglutinating antibodies compared to the vaccinated animals.

\section{Authors' Contributions}

AM did the experiments; HMS conceived the idea, planned the study, and wrote manuscript; PM maintained the animals in the farm. Both authors read and approved the final manuscript. 


\section{Acknowledgment}

Dr. Parkash Singh Brar, Director, Livestock Farms, Guru Angad Dev Veterinary and Animal Sciences University permitted us to carry out the study on cattle maintained in the University Dairy Farm and Dr. Mayank Rawat, Principal Scientist, Indian Veterinary Research Institute discussed with Hari Mohan Saxena about post vaccinal antibody titers in case of S-19 vaccine.

\section{Competing I nterest}

The authors declare that they have no competing interests.

\section{References}

1. Kollannur, J.D., Rathore, R. and Chauhan, R.S. (2007) Epidemiology and economics of brucellosis in animals and its zoonotic significance. Proceedings of XIII International Congress in Animal Hygiene. International Society for Animal Hygiene. p466-468.

2. Jain, U., Bisht, B., Sahzad, P.ragati. and Dwivedi, K. (2013) Outbreak of brucellosis in buffaloes aborted in a village Mahuan, district Mainpuri, UP, India - A case report. Vet. World, 6(1): 51-52.

3. Pandeya, Y.R., Joshi, D.D., Dhakal, S., Ghimire, L., Mahato, B.R., Chaulagain, S., Satyal, R.C. and Sah, S.K. (2013) Seroprevalence of brucellosis in different animal species of Kailali district Nepal. Int. J. Infect. Microbiol., 2(1): 22-25.

4. Godfroid, J., Garin-Bastuji, B., Saegerman, C. and Blasco, J.M. (2013) Brucellosis in terrestrial wildlife. Sci. Tech. Rev. Off. Int. Epiz., 32(1): 27-42.

5. Moriyon, I., Grillo, M.J., Monreal, D., Gonzalez, D., Marin, C., Lopez-Goni, I., Mainar-Jaime, R.C., Moreno, E. and Blasco, J.M. (2004) Rough vaccines in animal brucellosis: Structural and genetic basis and present status. Vet. Res., 35(1): 1-38.

6. Schuurman, H.J. (1983) The serological response of adult cattle to vaccination with reduced dose Brucella abortus S19, a trial under Zambian conditions. Vet. Q., 5: 94-96.

7. Schurig, G.G., Sriranganathan, N. and Corbel, M.J. (2002) Brucellosis vaccines: Past, present and future. Vet. Microbiol., 90: 479-496.

8. Avila-Calderón, E.D., Lopez-Merino,A., Sriranganathan, N., Boyle, S.M. and Contreras-Rodríguez, A. (2013) A History of the development of Brucella vaccines. BioMed. Res. Int., 2013: Article ID: 743509.

9. Morgan, W.J., Mackinnon, D.T., Gill, K.P.W., Gower, S.G.M. and Norris, P.I.W. (1978) Brucellosis Diagnosis: Standard Laboratory Techniques Report Series No. 1. MAFF, Weybridge, England.

10. OIE Terrestrial Manual. (2009) Brucellosis. OIE, Paris Ch. 2.4.3. p1-35

11. Williams, J.E. and Whittemore, A.D. (1971) Serological diagnosis of pullorum disease with the microagglutination system. Appl. Microbiol., 21: 392-399.

12. Sawada, T., Rimler, R.B. and Rhoades, K.R. (1982) Indirect haemagglutination test that uses glutaraldehyde fixed sheep erythrocytes sensitized with extract antigens for detection of Pasteurella antibody. J. Clin. Microbiol., 15(5): 752-756.

13. Oliveira, S.C. and Splitter, G.A. (1994) Subcloning and expression of Brucella abortus L7/L12 ribosomal gene and T-lymphocyte recognition of the recombinant protein. Infect. Immun., 62: 5201-5204.

14. Skendros, P. and Boura, P. (2013) Immunity to brucellosis. Sci. Tech. Rev. Off. Int. Epiz., 32(1): 137-147.
15. Bellaire, B.H., Roop, R.M. $2^{\text {nd }}$. and Cardelli, J.A. (2005) Opsonized virulent Brucella abortus replicates within nonacidic, endoplasmic reticulum-negative, LAMP-1positive phagosomes in human monocytes. Infect. Immun., 73: 3702-3713

16. Baldwin, C.L. and Goenka, R. (2006) Host immune responses to the intracellular bacterium Brucella: Does the bacterium instruct the host to facilitate chronic infection? Crit. Rev. Immunol., 26: 407-442.

17. Buck, J.M. (1930) Studies of vaccination during calfhood to prevent bovine infectious abortion. J. Agric. Res., 41: 667-689.

18. Rahman, H. (2012) National Control Program on Brucellosis: Aims and Strategies. Tech. Bull. PD-ADMAS, India (15).

19. Nielsen, K. and Duncan, J.R. (1988) Antibody isotype response in adult cattle vaccinated with Brucella abortus strain 19. Vet. Immunol. Immunopathol., 19: 205-214.

20. Long, G.Y., Liang, H.Z. and Liu, J.S. (1986) Immunization of rabbits against pasteurellosis. Chin. J. Vet. Sci. Technol., 2: 3-7.

21. Smits, H.L., Abdoel, T.H., Solera, J., Clavijo, E. and Diaz, R. (2003) Immunochromatographic Brucella-specific immunoglobulin $\mathrm{M}$ and $\mathrm{G}$ lateral flow assays for rapid serodiagnosis of human brucellosis. Clin. Diag. Lab. Immunol., 10: 1141-1146.

22. Ariza, J., Pellicer, T., Pallares, R., Foz, A. and Gudiol, F. (1992) Specific antibody profile in human brucellosis. Clin. Infect. Dis., 14: 131-140.

23. Smits, H.L. and Kadri, S.M. (2005) Brucellosis in India: A deceptive infectious disease. Indian J. Med. Res., 122(5): 375-384.

24. Hassanain, N.A. and Ahmed, W.M. (2012) Efficacy of serological tests in comparison with PCR for diagnosis of brucellosis. World J. Med. Sci., 7(4): 243-247.

25. Sareyyupoglu, B., Cantekin, Z. and Mustak, H.K. (2010) Investigation of Brucella antibodies in bovine sera by rose Bengal plate test (RBPT), serum agglutination test (SAT), microagglutination test (MAT) and 2-mercaptoethanol - microagglutination (2-ME-MAT) test. Ankara Univ. Vet. Fak. Derg., 57: 157-160.

26. Kimura, M., Imaoka, K., Suzuki, M., Kamiyama, T. and Yamada, A. (2008) Evaluation of a microplate agglutination test (MAT) for serological diagnosis of canine brucellosis. J. Vet. Med. Sci., 70(7): 707-709.

27. Versilova, P.A., Cernyseva, M.I., Aslanjan, R.G. and Knjazeva, E.N. (1974) Diagnosis of human and animal brucellosis by the indirect haemagglutination test. Bull. World Health Organ., 51: 191-197.

28. Chachra, D., Kaur, H., Chandra, M. and Saxena, H.M. (2012) Isolation, electron microscopy and physicochemical characterization of a brucella phage against Brucella abortus vaccine strain S19. Internet J. Microbiol., 10(2). DOI: $10.5580 / 2 \mathrm{c} 47$.

29. Ghodasara, S., Roy, A., Rank, D.N. and Bhander, B.B. (2010) Identification of Brucella species from animals with reproductive disorders by polymerase chain reaction assay. Buffalo Bull., 29(2): 98-108.

30. Malik, R., Gupta, M.P., Sidhu, P.K., Filia, G., Saxena, H.M. and Shafi, T.A. (2013) Comparative evaluation of indirect enzyme linked immunosorbent assay, rose Bengal plate test, microagglutination test and polymerase chain reaction for diagnosis of brucellosis in buffaloes. Turk. J. Vet. Anim. Sci., 37: 306-310.

31. Jain, S., Kumar, S., Dohre, S., Afley, P., Sengupta, N. and Alam, S.I. (2014) Identification of a protective protein from stationary-phase exoproteome of Brucella abortus. Pathog. Dis., 70: 75-83. 